\title{
Social business under the youth guarantee: Experience from the ground in Albania
}

\author{
Arlinda Ymeraj \\ European University of Tirana, Albania
}

Keywords

Social business, social welfare, social responsibility, social protection and inclusion, social exclusion.

\begin{abstract}
The paper "Social Business under the Youth Guarantee: Experience from the ground in Albania" deals with the model of Social Business, piloted in Albania, as a sustainable mode to encourage youth entrepreneurship and employment. The Albanian social business model, named Youth Albanian Parcel Service (YAPS), which employs exclusively disadvantaged youth, is an innovative example of new thinking on tackling social exclusion and reducing poverty.

Case analysis of YAPS (Youth Albanian Parcel Service), the successful Social Business Model established almost 20 years ago thanks to a harmonized multidimensional effort of key stakeholders, is used to bring in evidence from the ground to promote the novel concept of using efficiency and in-built sustainability of free markets to generate social wealth.

The evidence provided here shows that a new approach is emerging vis-á-vis social policies. A shift in thinking on social policy foresees the emergence of a social capital approach to social exclusion. This approach involves the mobilization of the entire community-including business actors and civil society leaders-in tackling social exclusion and empowering disadvantaged members of society.

Therefore, it is the government, which should bear the burden of finding ways to harmonize economic development with social policies. Although social business is perceived as relevant by all stakeholders, people are looking for clear guidance from the government because they still miss innitiative, financial resources and entrepreneurship education. Hence, the government may utilize economic levers to encourage the development of markets and competition; it may exercise its social role by implementing active labour market policies. Nevertheless, alongside them, the government must boost the education of people with the rules of democracy and the market, alike. These three roles are inextricably linked as they reflect the new political, social and economic order in which we live and secondly, because they determine a new relationship between citizen and the state in the post-communist era.
\end{abstract}

\section{Introduction}

The greatest challenge of Eastern and Central European countries is the social reform. The western literature has, at times, been tempted, and still may be, to consider income distribution in the former communist countries as an advantage of the system, assuming that equitable distribution was based on egalitarianism for all members of the society. Besides the Marxist theory, this viewpoint was also sustained by lack of realistic information on the former communist countries. Poverty in these countries did not exist only officially. As soon as transformation started in 1989, "transformation is not only changing political and economic institutions, but social stratification as well. The former collectivist welfare system is being rebuilt into a new one, placing far greater emphasis on market forces and individual responsibility and generating a new system of inequalities". (Delhey, p.5, 1998)

Post-socialist societies, newly emerging from totalitarianism and centralized economy, have been trying and continue to try to design frameworks to regulate the market economy and income distribution. Albania, too, since the fall of the communist system in 1991, has lived through a deep and radical transformation. After 45 years of isolation and oppression under the harshest communism of the region, it embarked on the road to building democracy through human rights protection and livelihood improvement in the context of a free market economy.

In the overall process of social development, guided by respect for human rights, a special place is taken by social policies designed not only to provide social and economic protection for the groups at risk, 
but also to contribute to their re-integration in society. An essential part of these policies is aimed at providing economic and social protection for vulnerable groups to help them being reintegrated into social life.

A shift in thinking on social policy foresees the emergence of a social capital approach to social exclusion. This approach involves the mobilization of the entire community-including business actors and civil society leaders-in tackling social exclusion and empowering disadvantaged members of society.

The social business model, as developed in Albania, in the creation of the Youth Albanian Parcel Service (YAPS), which employs exclusively disadvantaged youth, is an innovative example of new thinking on tackling social exclusion and reducing poverty. It promotes the novel concept of using efficiency and in-built sustainability of free markets to generate social wealth. According to the father of Social Business, Yunus, this enterprise is of the second type, in which a group of excluded and disadvantaged people enjoy their efforts to establish and manage a business enterprise, mostly supported by a trust (Yunus, p.2, 2013).

This paper tackles the government's role on finding ways to harmonize economic development with social policies. While states struggle to take on the fiscal burden of supporting their most vulnerable citizens, societies such as Albania have paid witness to a dramatic growth in resources in a fledgling private sector. However, "economic activity often operates in a binary rather detached and isolated from both public sector and civil society. The brutal and predatory individualism encountered in many enterprises is in sharp conflict with the social interests of the state and society at large". (Zamagni, p.7, 1997)

The arguments advanced in the paper proceeds as follows: Section II briefly explains the methodology as well as the study limitations, while section III examines the evolution of the Social Protection and Inclusion policy in Albania and the institutional arrangements it has shaped. Section IV, which comprises the core theoretical component of the paper, argues the case that social business's experience may serve to formulate a new approach to social protection. Section V elaborates overall conclusions, addressing the new roles of the state in countries in transition.

\section{Methodology and limitations of research}

In fully alignment with the research goal, a descriptive methodological approach firmly based on data gathering from primary and secondary sources, was implemented. The method employed was a combination of systematic and meticulous desk review of all available documents (primary sources) and a set of interviews with YAPS key stakeholders (secondary sources). The research aims to carry out an assessment of YAPS, the first and the only Social Business Model in Albania, a good practice of disadvantaged youth empowerment to identify some lessons, which may support model replication and impact on economic growth, reduction of unemployment especially among youth and enhance greater social cohesion.

Face to face interviews with stakeholders include employees, managers, administrative board, and YAPS key customers. Semi-structured questionnaire, the research instrument served to collect qualitative information. However, the effectiveness of the research work is limited by the size of the study case as well as by the weight and role of Social Business vis-à-vis the overall income generated by private business, even from the small and medium enterprises. Hitherto, rather than an economic lever, YAPS is perceived as a social empowerment enterprise.

\section{Social Protection and Inclusion in Albania}

There has been a tendency, in various studies, to consider the social relationships of the socialist system as one of its strongest advantages. These countries, even the smaller ones, are included among modern societies when only physical and human capital is considered: the spread of literacy, urban population, modern communication, and information characterize most of these countries today. (Ymeraj, p.87, 2018). However, the critical issues of transition and frequent crises have shown how inaccurate and insufficient is the evidence of social capital in these countries.

What has been called 'the new human being of the Communist era' has been seriously deformed. It was totally impossible to recognize real social values, due to oppression by and fear of the regime. During transition, the state and the market remain influenced by past ideology and by the legacy of historical 
development. The rapid polarization of society and the accumulation of wealth in a few hands have deepened the process of impoverishment, the middle class being more affected due to unemployment, very low incomes, emigration and disruption of social and community relations. Thus, the tendency to advance towards democracy has been confronted by the bleakness of the social basis. (Ymeraj, p.89, 2018).

Most analysis concerning countries' development refers to macroeconomics performance indicators, putting aside the concept of 'social inclusion'. It has been generally accepted that a strong economy creates a suitable environment for social progress, which applies in practice up to a point. However, when referring to post-Communist countries there are two different realities. While the first refers to the market economy promoting social welfare, post-Communist countries are applying the opposite: in their case, 'social mobilization' transforms, encouraging the market to develop, which in the end turns towards social welfare.

Since the beginning of the last century, Albania, a small country in the Balkans, with an area of 28,748 square kilometers and a population of 3,187,384 people (INSTAT, 2011) has been characterised by heterogeneous governance, marked by striking disregard for the stage of social development, which has affected the nature and the development of social capital. Despite economic growth of 4 to 5 percent in the last years, poverty and social exclusion remain critical, and the country is among the poorest in the region, with a poverty headcount ratio of $37 \%$ in 2020 (http://data.worldbank.org/country/albania) at national poverty line.

Today, Albania's case exemplifies a traditional society making some sporadic efforts to become a modern one. This can be seen in both the market and the state sectors where large, impersonal bureaucratic organizations break the rule of law in their operations. (Rose, 1998). Moreover, informal networks substitute for formal organizations in politics, using bribery and corruption. Communities do not oppose such informal networks, being too weak to do so. Lack of social responsibility is both an output and an input, continuously generating a loss in social capital.

The negative economic legacy of the past and a difficult economic transition has caused economic instabilities coupled with deepening social and economic inequalities between the rural and urban parts. As a direct result of the cultural change, the entire population is exposed to a range of risks with bearing on the economic situation of the families and individuals, while opportunities to benefit from social service delivery remain limited. (UNICEF, NCSS \& URI, 2011, p.34).

The Albanian Social Protection mechanism, established from scratch in 1992-1993, is designed to addresses the economic and social dimensions of exclusion, alike. However, guided mainly by the criteria of macroeconomic balance maintenance and the limited budget, the social protection mechanism while providing benefits fails in promoting people to be socially integrated. The policy of social protection, defined as the policy of 'alleviation of social inequalities' is not sufficient to promote the social development of Albanian society, while the recipients of social assistance are the most vulnerable to social exclusion. They suffer from multiple social disadvantages because they lack access to basic standards of housing, education, health, human relationships, and protection. Beyond straight forward economic poverty, the use of term social exclusion recognizes that the human rights of the individuals can be further threatened by the forced passivity of welfare, the inability to fulfil their basic potential and to build the kind of human relationships that lead to active citizenship. The traditional approach of social protection is no longer relevant for Albania. The social policy must be re-shaped, while "Social Business" may serve as a "start-up model" to encourage disadvantaged people to look for a change.

\section{Social Business, a new approach vis-à-vis the traditional social protection policy}

Social enterprises are businesses with social objectives whose profits are channeled back to the community to serve social goals. They are market driven and value led. Social enterprises tackle a wide range of social and environmental issues and operate in several domains of the economy.

The evolution of social enterprises was triggered by the blurring of sector boundaries between private and public. The recent unparalleled economic expansion: globalization and the spur of new technologies fundamentally questioned the reigning separation of the private and public sector. Multinational corporations faced with growing grassroots activism calling for corporate responsibility have gradually changed their perspectives on the sole profit-making role prescribed to corporations. At the same time, international donors and governments believed that the social sector fell far short of remedying social ills. 
Little change has been noted in the welfare of societies thus consequent phasing out and donor fatigue left not-for-profits to struggle financially. Donors and governments have been repeatedly asking for sustainability as a pivot point for giving support to mushrooming NGOs.

The buzz word has become a financial term called double bottom line which required all entities to simultaneously meet financial and social goals. The new models engulf a corporation which is socially responsible and an NGO which is not grant dependent. On one hand, corporations with the wellentrenched slogan 'good business, good neighbor' reached out to local communities by supporting varying social initiatives. On the other, NGOs sought avenues to serve their social missions by developing self-sustaining businesses in the market. The new hybrids successfully blended for-profit and not-forprofit elements in their ventures.

Social enterprises have been sprouting in a variety of countries in different economic and business environment. This new field amalgamating business acumen and social sensitivity aims to meet the challenges of a changing world with converging boundaries between business and public. The social business model gives us great opportunities to boost both the economy and the society simultaneously building on business success and harnessing social well-being.

Social entrepreneurship can take many forms and serve many objectives. The oldest breed is workforce development initiated by governments and microfinance projects supported by international organizations. The more recent model represents not-for-profit organizations transforming into business ventures to achieve long-term social impact. The newest social business venture conceptualized by a unique collaboration among business, private and social actors in Albania has set up a business - without building on a previously existing not-for-profit - to meet a social objective.

Youth Entrepreneurship has been a response to persistently high unemployment among youth in industrialized countries. The restructuring of labor allocation, shift to small-scale production and service sector from concentrated industrial production, and relocations of companies to countries with cheap labor led to unemployment. Even those young people who could find employment were faced with less favorable conditions, as often they were offered short- term contracts without benefits.

Youth unemployment did not only plague the industrialized countries but has been identified as one of the key development issues in Southeast Europe (SEE) following the transition periods. In SEE unemployment among youth especially marginalized social groups and women is higher than that of adults. Eroding social safety net and limited opportunities coupled by traditional nepotism in public sector jobs led to devastating consequences. Brain drains and massive migration caused tremendous loss in human capital. Long-term youth unemployment is likely to cause social problems. It increases the chance that young people get involved in illegal activities; engage in risky behavior such as drug use, violence and prostitution.

Governments encouraged the idea of self-employment and the development of entrepreneurial skills in order to reduce the risk of marginalization of young unemployed. Curricula at schools have been extended to include basic training and skills in self-employment, business administration, economics etc. Favorable environment for youth entrepreneurship was created by mentor support, access to finance and workspace, and start-up loans. Governments offered incentives for companies that employ youth.

Several attempts have been also taken by the private sector, international and non-governmental organizations. There have been initiatives by the private sector to organize on-site visits, career days and even finance the school fees of talented youth. International and non-governmental organizations adopted the idea of social entrepreneurship to especially target youth of low socio-economic background and atrisk youth.

In 2001, a coalition of private and public sector actors, under the leadership of UNICEF, developed a social business approach to reducing social exclusion. The Youth Albanian Parcel Service (YAPS) is a classic social business in the sense that it uses wealth creation to achieve social goals. Funds and expertise have been generated by the private sector to develop a courier service that exclusively recruits socially excluded young people.

The business component of the venture envisaged quality domestic mail and parcel delivery services delivered at competitive rates. The social component envisaged recruitment and training of young victims of socially exclusion, as those described in the previous section plus migrant youth that represent 
additional strata of social exclusion within Albania. Profits generated by the young people would be ploughed back into expanding and developing social business opportunities for a wider band of youth. This virtuous circle would enable the young people, not only to turn their own lives around, but at the same time to become agents of social cohesion. (UNICEF, p.12, 2001).

UNICEF managed to raise over US\$300,000 in funds with the primary donor being Banca Intesa, a leading commercial bank in Italy and in Albania. A KPMG market survey of 114 leading banks, firms and institutions in Tirana revealed extensive demand for courier services. Indeed no domestic courier services were available in 2001. Simultaneous to the market survey, an independent consultant was hired to conduct a detailed feasibility study and business plan. Within the business plan, a cash flow forecast projected post tax profits moving from US $\$ 17,005$ per annum to US $\$ 27,716$ per annum within the first three years of trade. The cash flowforecast was based upon an examination of both market demand and the capacity that the contribution from Banca Intesa would enable YAPS to have.

These calculations foresaw the delivery of parcels growing from 69,873 deliveries per annum over the first three years of trade to 232,910.(UNICEF, p.16, 2001). A cash flow forecast is not a scientific announcement of a given outcome, but rather a set of navigational indicators that can inform the strategic direction of a venture. But using the thorough research that had been carried out by both surveys, UNICEF and the founders concluded that they could invest the money in the establishment of YAPS in Albania with a high probability that even a considerably more modest success than predicted would have the desired impact of employing a significant number of socially excluded youth.

A total of US\$308,679 was directly invested in the establishment of YAPS. This covered the cost of recruitment, training, construction of a purpose-built premises (1/3 of total cost), procurement of equipment,market research, marketing, initial wages and management services. The availability of a relatively large sum of funding enabled a smooth and rapid set up process together with the capacity to provide high quality services from the outset.

After 20 years, YAPS is still in the market, with a complex package of services in addition to courier ones, like electrical supply repairs and maintenance, cleaning services, IT maintenance and other required services. During the last 10 years, the number of employees has almost tripled, from 70 to 180. During the last decade, from 2010 to 2020, the volume of services provided by YAPS has increased by 8 times (from 15.000 services per year in 2010 to 120.000 services in 2020), whilst the number of clients only for the cleaning and maintenance services has increased by 3,5 times (from 25 clients in 2010 in 94 clients in 2020). Net profits have also increased by three times, from US $\$ 250,000$ in 2010 to US $\$ 800,000$ in $2020 .{ }^{1}$

What does the YAPS experience show? YAPS has definitely made a real difference in the lives of the individual young workers involved. They are new persons with new lives and with futures that they or others thought they would never have. The initial impact of YAPS therefore is to break the cycle of passivity and hopelessness in the lives of a given number of individuals and provide an hitherto unavailable opportunity to shift from passive to active members of society.

While the dramatic results in young people's lives are widely recognized, there is the realization that YAPS and social business is not the panacea to the immense complex of social needs of young people. It is seen as a valuable piece of a broader web of social protection measures, and not a stand-alone solution. It is a high-investment venture but with significant returns on investment.

YAPS is a clear message that a new approach to social protection is needed, different from the traditional one. The new Social Protection mechanism, while helps the poorest to actively come out of poverty, promotes them as well to be socially included. Therefore, the transformation of the current system into a 'social protection, integration and inclusion mechanism' has to come to the forefront of the agenda.

YAPS experience demonstrates also that a new and vital partnership model is required, in which despite the nature and institutional organization, stakeholders are united by the mission and common objective of supporting people to alleviate shocks of transition through the provision of holistic and comprehensive social services. It proved that the effective collaboration between foreign and domestic

1 Interview with Mr. Arben Shamia, YAPS General Director, February 2020. 
actors and partners, and between the partners and beneficiaries, has been the fundamental factor of success so far.

As a matter of fact, this experience helped to understand that provision of social wellbeing is neither a product nor a duty of one institution, therefore, there cannot be "one" provider. It is a product of many "actors" - governmental and nongovernmental, of the central and local government, public and nonpublic, which can and should take their social responsibilities for the sake of society.

\section{Conclusions: the new roles of the state}

After the failure of the communist system, the question of the state's role in Eastern European countries, including Albania, is debatable and controversial. Some politicians argue that the economic role of the state must be separated from its political role, contending that the state in the past failed because of its inability to separate economic and political spheres. But as long as political power stems from economic power, it is not possible to separate economics from politics. They are interlinked with each other. "Economics will remain profoundly political, not only because this is the case in every politicoeconomic system, but because in the specific context of East Central Europe the task of economic transformation presents unprecedented political challenges" (Batt, p.5,1991).

Whereas political transformation was desirable for the people, economic and social transformation was painful. The implementation of transition reforms required strict macroeconomic stabilization policies implemented alongside privatization, liberalization of prices and trade, fiscal and monetary policy, banking reform and opening of the economy. The social pain which accompanied the implementation of these policies discouraged people, who had other expectations. "For a considerable part of the society the understanding and accepting of the rules of market economy finishes at the level of expectations of quick success and reaching a Western standard of consumption". (Barr, p.32, 1991).

In such a challenging development context, the government should have strategically and courageously intervened to create, to regulate and improve. In poor countries like Albania, characterized by weak social protection mechanisms, Social Business is an effective alternative to empower disadvantaged people and create jobs.

The government can create an enabling environment for social business through the provision of tax concessions and incentives like VAT on services or goods, exemption from small business tax, income tax of employees or tax concessions for both donors/businesses and recipients of cash and services provided in support of social business. Meanwhile governments benefit from a reducing burden on basic welfare payments and the more acute costs of the fall out from social exclusion of at-risk youth eg, imprisonment, conflict, violence, post-drug rehabilitation etc. The difference between social business and business, from a government perspective, therefore, is that social business is an instrument for redistribution of public funds and social investments with an improved outcome for its most vulnerable citizens.

Another role of the state could be in the provision of education/vocational training in support of initial employment of disadvantaged youth. A long-range goal of ventures such as YAPS may also be enabling employees to eventually attend university and proceed on their own career path while Social Business recruits' new generations of disadvantaged youth for employment. The government could be supportive of this process and at the same time benefit from the impact of positive role models of university educated care leavers or disabled youth upon younger generations of similarly disadvantaged youth. The state may also be able to provide cash assistance from social fund toward social business.

A key step to achieving all of the above would be the development of a specific law on social business which would outline the package of concessions and support available to new social business ventures. Such law may promote the incentives of private sector actors in social actions, as well. This is beyond the remit of this paper. However, the experience of social business here in Albania, has been that business leaders are much more interested in getting to engage in social actions when their skills and expertise are utilised, and they can see tangible social and business outcomes. Thus, social business provides the opportunity to shift from the traditional role of the businessman passively providing funds to a hospital wing or an orphanage to them coming on board at exactly the point where they are able to have the strongest impact, creating wealth. 
Social business provides NGOs with the opportunity to access additional resources to achieve their goals of social action and empowerment. Equally their experiences are crucial in developing methodologies for reaching out to and eventually integrating disadvantaged youth.

The government is a natural stakeholder in social business. It is responsible for the success of the transition from a communist socio-economic structure to a liberal democracy. Most importantly, through policies and institutions, it shapes the shared values and ethics of its constituency as they adapt to a changing world.

The transition reforms in Central and Eastern European countries have shown that rapid progress from a centralised to a liberal model cannot be realised without strong intervention by the state. The government is the link between privatisation, foreign investments, financial policies, and the administration that puts them into practice. The role of government is not only to focus on the legal framework, but also to apply this framework through the decentralisation of services and the consolidation of individual responsibilities. Otherwise, the establishment of a legal system has no useful function and the three roles of the state - economic, social, and developmental - cannot be implemented.

However, nowadays new important actors are willing to undertake responsibilities. State is no longer the only "duty bearer" as regard social protection. Every day, citizens and civil society as well become more accountable vis-à-vis "rights holders". Nevertheless, they cannot substitute the role of the state, but they complement it if the government exercises its power to align, leverage and harmonize stakeholders' contributions. YAPS experience clearly demonstrates that anything is possible if people harmonize their efforts to achieve results.

\section{References}

Barr, N. (1987). The Economics of the Welfare State, Great Britain. Biddles Ltd.

Barr, N. (1994). Labour markets and Social Policy in Central and Eastern Europe. New York: The IBRD.

Batt, J. (1991). East Central Europe from reform to transformation. London: Pinter.

Bird, G. (1992). Economic reform in Eastern Europe. E. Elgar: UK.

Delhey, J. (1998), Inequality and Support for Redistributive Policy: One World of Post-Communism, Two

Worlds of Western Capitalism. Abteilung "Sozialstruktur und Sozialberichterstattung" im

Forschungsschwerpunkt III, Wissenschaftszentrum Berlin fur Sozialforschung (WZB).

http://citeseerx.ist.psu.edu/viewdoc/summary?doi=10.1.1.376.4844

Rose, R. (1998). Richard, getting things done in an anti-modern society: Social Capital networks in Russia, Social Capital Initiative. Working Paper No.6. The World Bank.

Shamia, A. (2020), YAPS progress, face to face interview.

Zamagni, S. (1997), The crisis of Welfare state: Government and social welfare. Milan; Mondadori.

Ymeraj, A. (2018), Government as a key duty bearer in transition reforms from socialism to capitalism-the case of Albania, ESJ Journal, November 2018, Vol.14, No.32, p.84-102.

Yunus, M. (2013). Building Social Business (Ndërtimi i biznesit social). Tiranë: UET Press.

UNICEF Albania Archive. (2000). YAPS Feasibility Study and Business Plan.

UNICEF Albania Archive. (2001). Globalization with a Human Face. RL/alba001.

UNICEF Albania, NCSS and URI. (2011). Reformation of social assistance: from survival to investment in poverty reduction. Published by UNICEF Albania, Tirana, 2012. 